\title{
Toulouse dykes: reducing failure hazard combining structural reinforcement works and organization measures
}

\section{Jérémy Savatier ${ }^{1, a}$, Nicolas Pépin ${ }^{1}$, Gwendal Sénéchal ${ }^{1}$, Caroline Zanetti ${ }^{2}$, Nelly Liency ${ }^{2}$, David Morellato ${ }^{3}$, Laurent} Fourquet $^{3}$, Jean Philippe Saquet ${ }^{4}$, Dorine Jouathel ${ }^{4}$, Nathalie Libourel ${ }^{5}$, Stéphane Watellier ${ }^{5}$

${ }_{1}^{1}$ ISL Ingénierie, 15 rue du Maréchal Harispe, 64500 Saint Jean de Luz, France

${ }^{2}$ Arbeausolutions, 100 impasse des Houillères, Le Pontet, 13590 Meyreuil, France

${ }^{3}$ DDT31, Cité Administrative, 2 boulevard Armand Duportal, 31074 Toulouse, France

${ }^{4}$ Toulouse Métropole, 6 rue René Leduc, 31505 Toulouse, France

${ }^{5}$ Mairie de Toulouse, 1 place du Capitole, 31000 Toulouse, France

\section{Abstract.}

Toulouse dykes include $16 \mathrm{~km}$ of various types of dykes and flood gates and stoplogs, belonging to several owners including Toulouse City and French State (DDT31) that own about $13 \mathrm{~km}$. The Toulouse dykes Hazard Study has been made in 2014-2015. The study includes:

- An estimation of the probability of failure, evaluated as low, including for the 1875 reference flood, except on a few dykes sections that were already planned to be reinforced.,

- An estimation of the severity in case of failure (population exposure) by flood hydraulic modelling. Toulouse city being an important city, the population exposure in case of dyke failure is quite high.

- An assessment of the criticality of the different dyke sections. The criticality level of the dykes has been globally estimated as acceptable, after planed works will be completed.

Temporary mitigation measures have already been included in the flood management plan, and consist in preventive evacuation of exposed population for flood levels lower than the 1875 reference flood level, as long as the reinforcement works are not completed. Several additional mitigation measures have been proposed such as: structural reinforcement of a few dykes section, a vegetation management plan, and improvement measures of the flood management plan and the need to continue regular training emergency exercises.

\section{Presentation of dykes and protected areas}

Toulouse dykes include more than $16 \mathrm{~km}$ of various types of dykes (gravity walls, earth dykes, coated embankment dykes, historic building walls), flood gates and flood barriers, belonging to several owners including French State (DDT31), with about $13 \mathrm{~km}$, and Toulouse City $(3 \mathrm{~km})$.

The typical height of the dykes ranges from 1 to $5 \mathrm{~m}$ above the level of the city ground.

The nature and characteristics of the dykes and their foundation are globally well known thanks to historical archives, previous studies, structures drawing and description, geotechnical investigation and topographical survey [1].

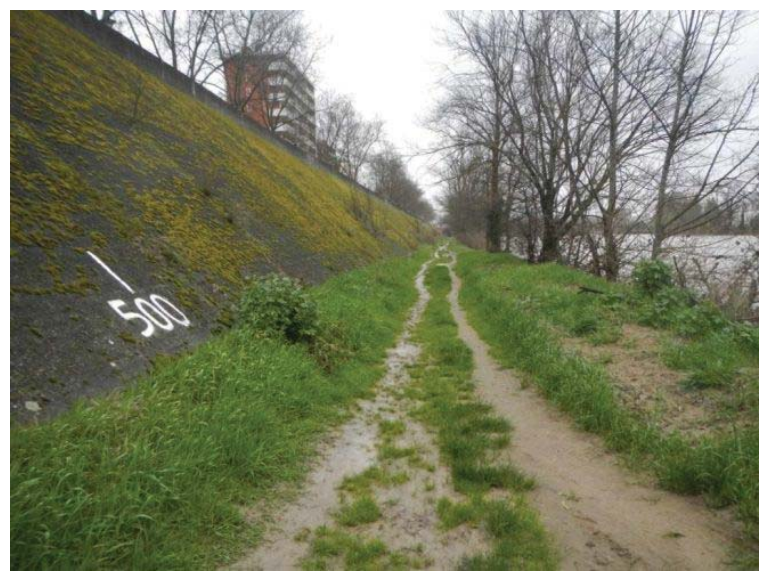

Figure 1. Example of coated embankment dyke

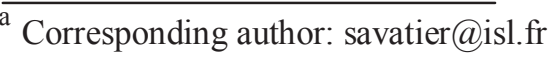

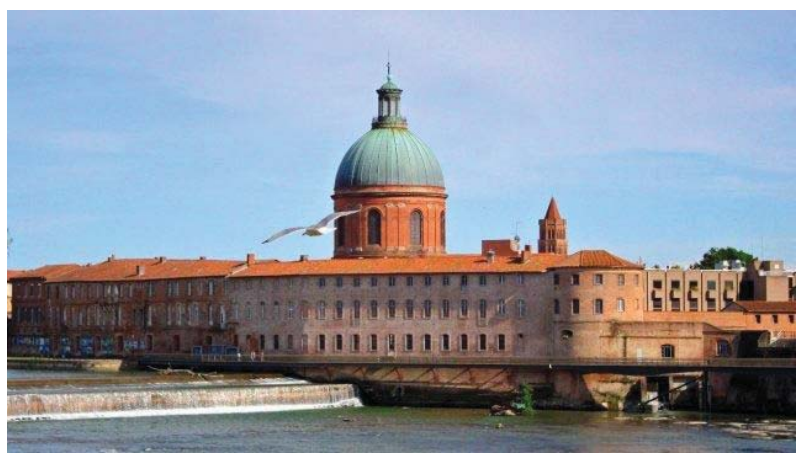

Figure 2. Example of historic building wall (Toulouse hospital)

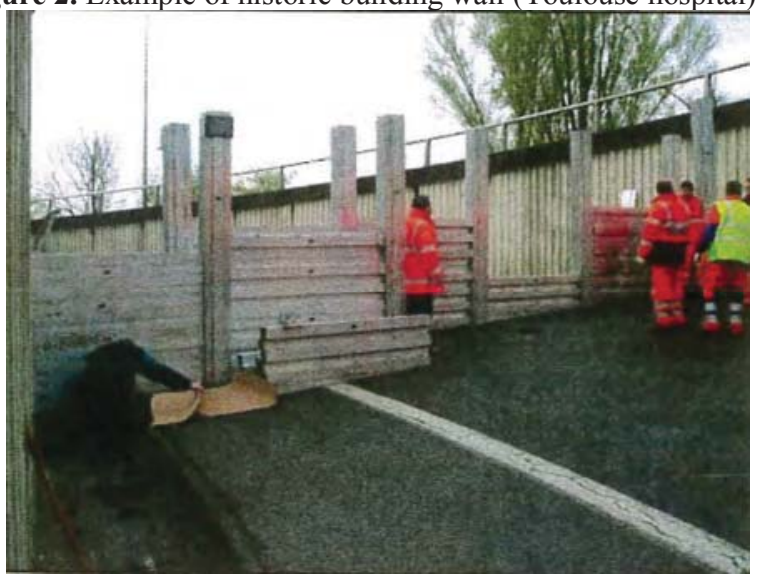

Figure 3. Example of flood barrier (from DIRSO)

The dykes form three different protected areas with a total of about 65000 inhabitants and about 40000 jobs according to data from the national institute of statistics [1]. 


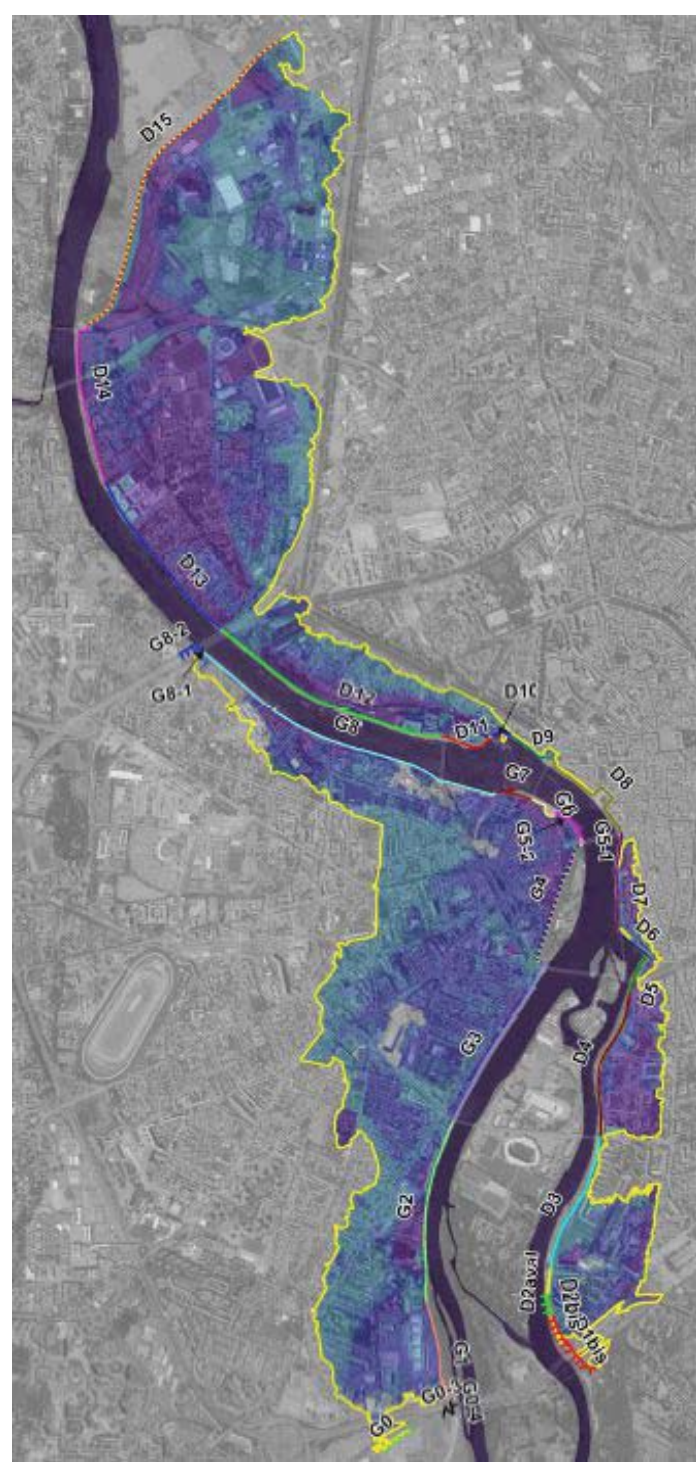

Figure 4. The three protected areas and dykes' denomination

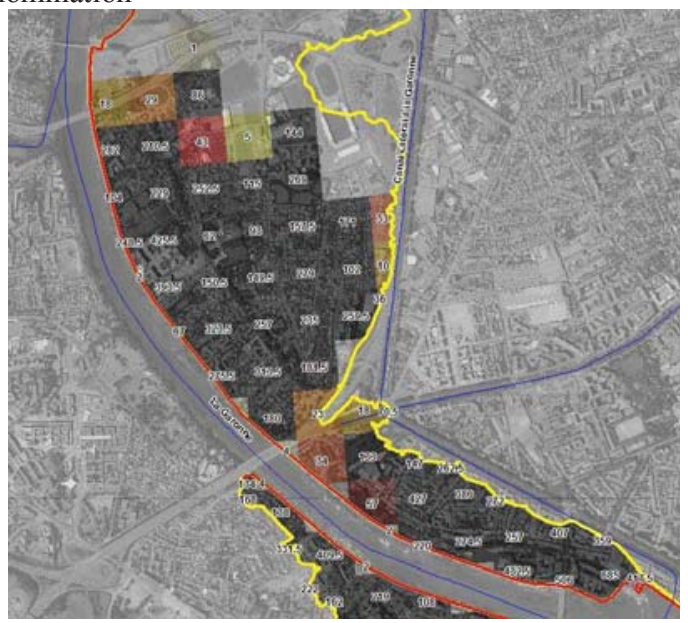

Figure 5. Protected population estimated thanks to data form the national institute of statistics.

\section{Risk analysis}

\subsection{Floods}

The historical 1875 type flood, which is the reference flood for urban planning ("Plan de Prévention des Risques d'Inondation") and the dyke design flood, has a $7500 \mathrm{~m}^{3} / \mathrm{s}$ peak flow rate and a return period of about 400 years according to flowrate statistical analysis based on the period with available data (1910-2014) and on larger periods taking into account historical level and flow rate estimation data (1875-1910) and historical record of major floods (1770-1875) (cf figure 7).

The oldest dykes situated in the city center have known the 1875 flood. Nevertheless, most of the dykes were built after the 1960's and have not experienced any significant flood. Since then, the greater flood is the one of 2000 , of about $3740 \mathrm{~m}^{3} / \mathrm{s}$ and 25 year return period. It has barely solicited the dykes.

The risk analysis is led for 4 flood levels:

- the 100 year return period flood, flow rate estimated to $5100 \mathrm{~m}^{3} / \mathrm{s}$

- The $8250 \mathrm{~m}^{3} / \mathrm{s}$ flow rate flood, that reaches $50 \mathrm{~cm}$ above the 1875 flood at the gauging station

-The 1875 and 2000 floods mentioned previously.

Flood durations are a few tens hours and the flood rising speed ranges form $25 \mathrm{~cm} / \mathrm{h}$ to $50 \mathrm{~cm} / \mathrm{h}$.

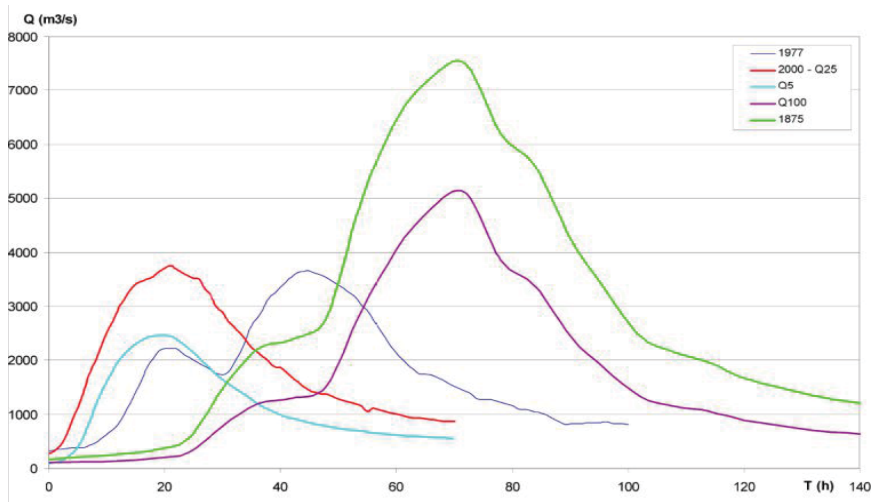

Figure 6. The flood hydrographs

The water levels of these floods are known along the dykes thanks to previous 2D hydraulics models. 


\section{FLOODrisk 2016 - $3^{\text {rd }}$ European Conference on Flood Risk Management}

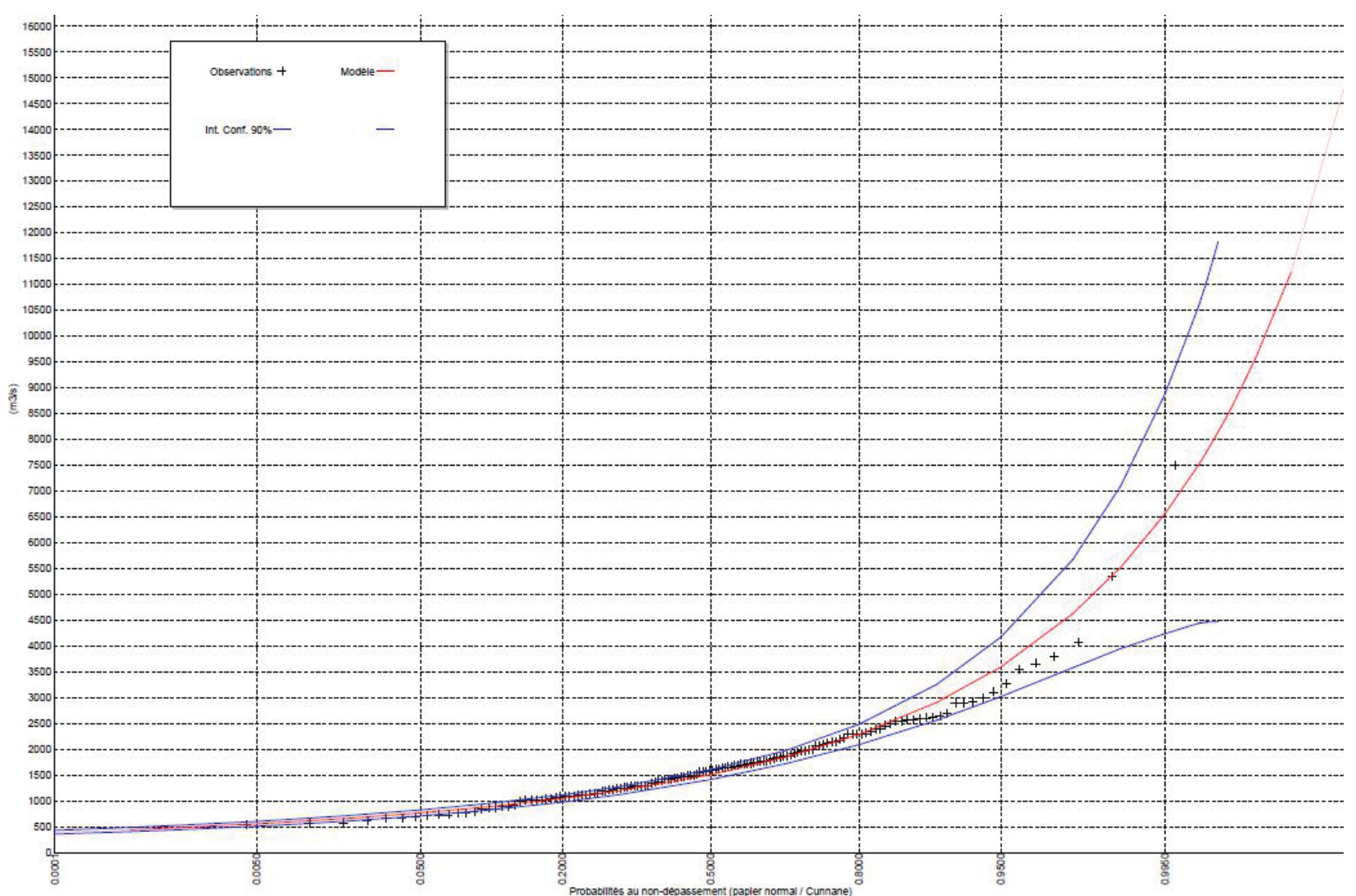

Figure 7. Reverse Gamma adjustment of annual maximum flow rate over 1875-2014 period

\subsection{Dyke failure hazard probability}

Dyke failure hazard probability has been estimated for the 4 different floods and the 26 homogenous dyke sections, through a semi-expert assessment method for the 4 main failure modes [5] [6] :

- Overflowing

- External erosion

-Internal erosion

- Stability

\subsubsection{Overflowing failure hazard}

For the overflowing failure hazard assessment, the solicitation is the overflowing water height and the duration of the overflowing.

The resistance criteria are assessed according to the dyke type:

- For earth dykes and coated embankment dykes, with downsteam facing erosion risk : dyke geometry (width, downstream facing slope), nature and state of the downstream facing; presence of parapet wall and height, impact of vegetation;

-For the gravity walls, with downstream toe scouring risk: toe coating, downstream facing height, presence of parapet wall and height, impact of vegetation.
A rating scale is then applied to evaluate overflowing failure probability during a flood event:

\begin{tabular}{|l|l|l|l|l|}
\hline \multicolumn{5}{|l|}{ Overflowing resistance level } \\
\hline $\begin{array}{l}\text { Maximum } \\
\text { water height }\end{array}$ & $\begin{array}{l}\text { Very } \\
\text { high }\end{array}$ & high & medium & low \\
\hline$-2 \mathrm{~m}$ à $-40 \mathrm{~cm}$ & $<10^{-4}$ & $<10^{-4}$ & $<10^{-4}$ & $<10^{-4}$ \\
\hline-40 à $-10 \mathrm{~cm}$ & 0.001 & 0.003 & 0.007 & 0.01 \\
\hline-10 à $10 \mathrm{~cm}$ & 0.01 & 0.03 & 0.07 & 0.1 \\
\hline 10 à $30 \mathrm{~cm}$ & 0.02 & 0.05 & 0.1 & 0.3 \\
\hline 30 à $50 \mathrm{~cm}$ & 0.05 & 0.1 & 0.3 & 0.7 \\
\hline$>50 \mathrm{~cm}$ & 0.1 & 0.3 & 0.7 & 1 \\
\hline
\end{tabular}

Table 1. Overflowing failure assessment rating scale (probability of failure).

\subsubsection{External erosion}

External erosion risk results from two possible phenomena:

- Erosion by the water velocity on the upstream facing of the dyke,

- Erosion due to river bed mobility and scouring of the dyke toe.

Solicitation is assessed according to flow velocity and Shields shear stress.

Resistance criteria are:

- Existence, nature and state of coating on upstream facing of the dyke,

- Width of the dyke,

- Width between the riverbed and the dyke,

- Presence of cut off protecting from scouring 


\subsubsection{Internal erosion}

Solicitation is assessed according to the mean hydraulic gradient (ratio between the hydraulic load and the width of the potential internal erosion hydraulic path).

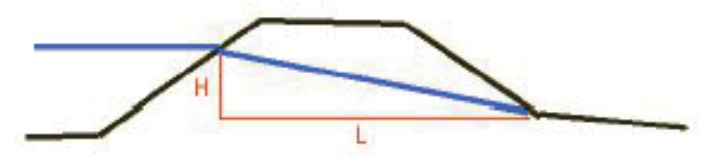

Figure 8. The mean hydraulic gradient

The resistance criteria are assessed according to [7] [8]:

- Available information on nature and properties of dykes filling and their foundations,

- Adverse factors such as the existence of embedded structures, fissures, vegetation,

- Positive factors such as the existence of coating or cut off, existence of filter or drainage.

Along the embedded structures, the Lane criterion [9] is also evaluated.

\subsubsection{Stability}

Risk of failure by instability has been assessed mainly on existing stability studies including calculations made during previous diagnosis studies.

For 6 earthfill dyke sections, no stability study was available and the stability was assessed according to:

-The hydraulic load,

-The resistance criteria: crest width and downstream facing slope, nature and compaction of the fill.

\subsection{Building wall failure probability assessment}

On the building walls, the stability of the masonry walls themselves has not been found to be an issue, due to their width (about $2 \mathrm{~m}$ ) and the relative limited hydraulic load. Windows are equipped with glass designed to resist to the hydraulic load and are either fixed or openable (cf figure 10).

Specific organization has been set in order to close the windows whenever nobody is in the offices and to check they are properly closed in case of flood alert.
An uplift risk of the floor apron has been identified in some rooms.

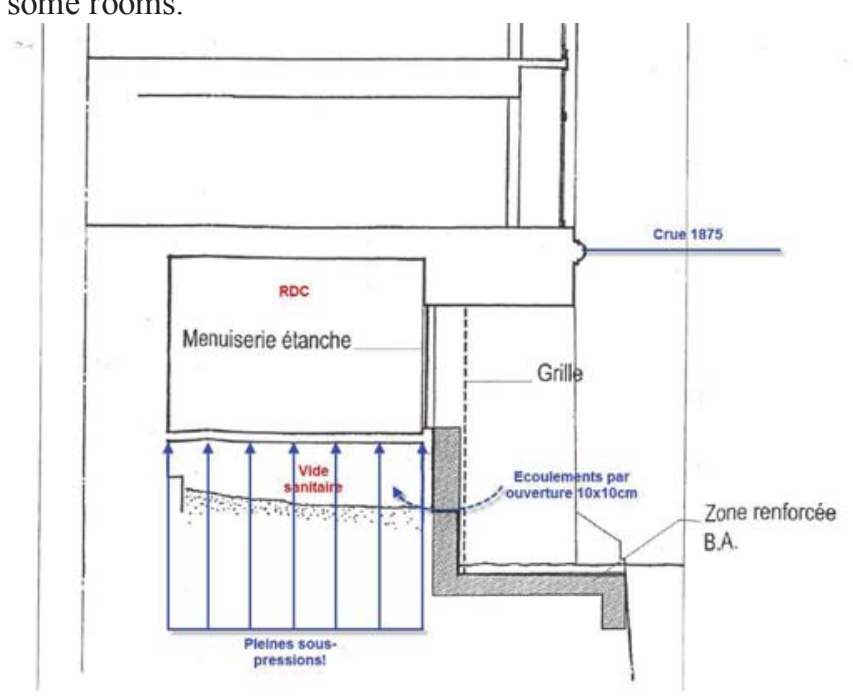

Figure 9. Uplift risk (Toulouse hospital)

\subsection{Dyke vegetation diagnosis and impact on failure hazard}

The vegetation diagnosis [2] is based on existing plant and tree species observation, as well as their origin location, stage of development, density and dimension of the woody species trunk base and also their sanitary and mechanical conditions [10].

The aspects such as size, dykes constitution, bank shapes, coating shapes, surface uplift, collapse, subsidence, cracking or different disorders are integrated in the analysis in order to merge the vegetation and the structural parameters. These aspects will allow determining the diagnosis of induced risks in order to characterize their typology.

The diagnosis target is to evaluate risks for structures in order to define the decisive actions to be taken on dykes, in terms of dyke restoration and vegetation maintenance. A total of 1533 trees and 118 lines of trees have been identified, which represent a cumulative linear of about $3.4 \mathrm{~km}$.

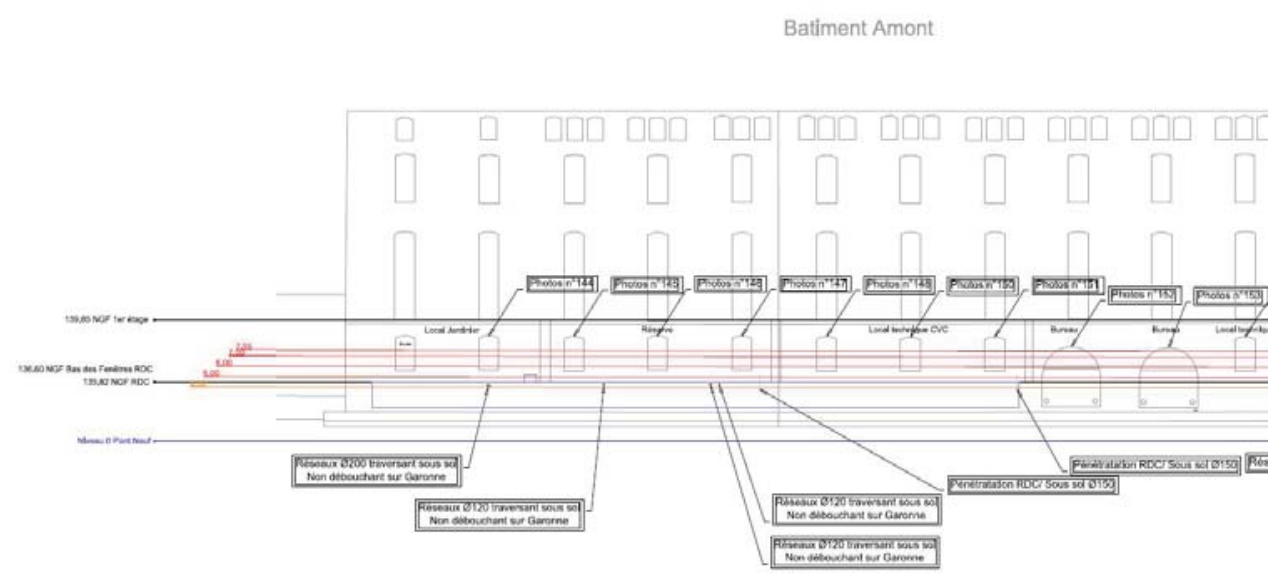

Figure 10. Building elevation with flood levels (from Toulouse Hospital) 


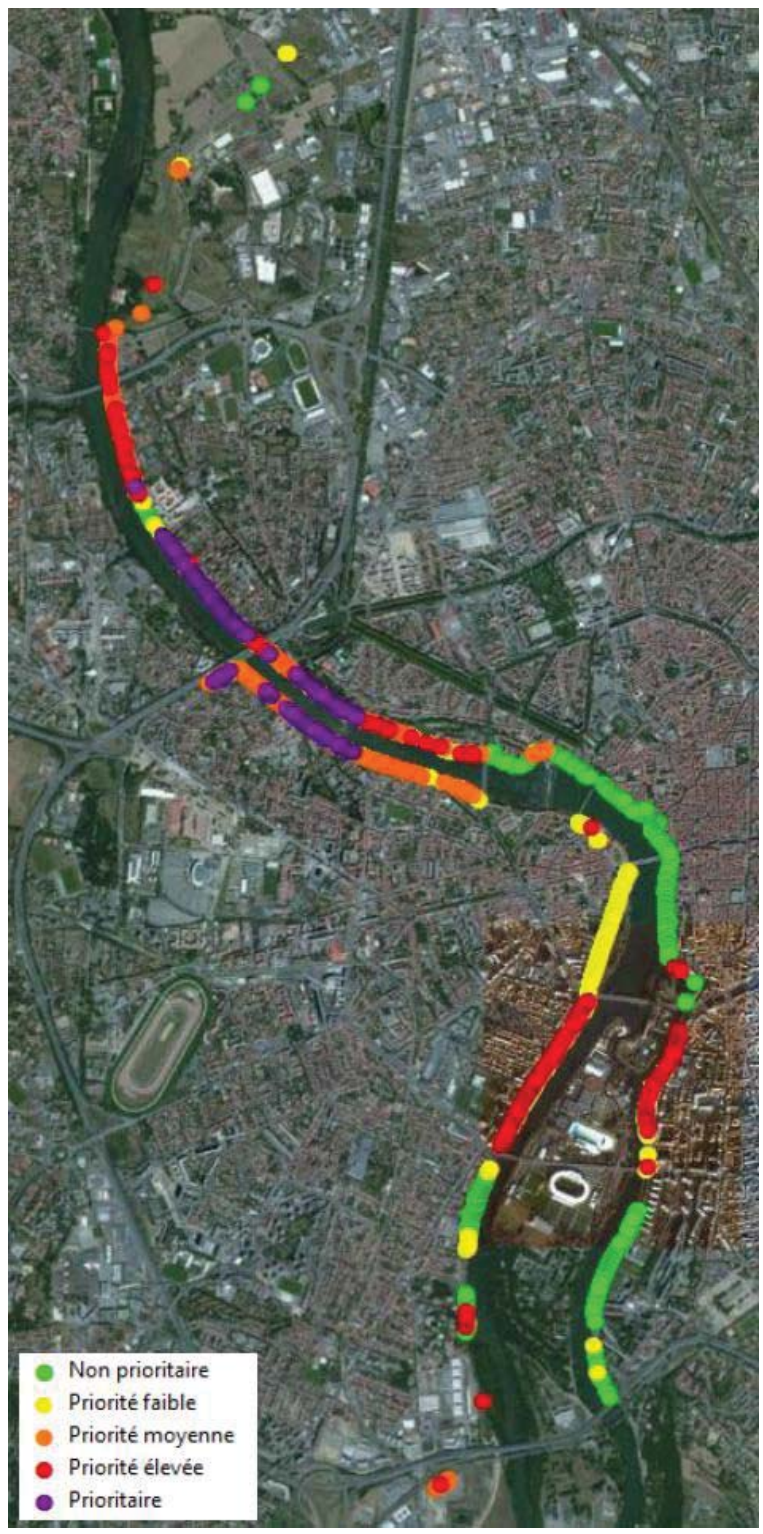

Figure 11. Trees and lines of trees observation

In the case of vegetation diagnosis on Toulouse dykes, 5 types of risks generated by trees have been distinguished, corresponding to the different ways of failure such as:

\subsubsection{Vegetation and internal Erosion Risk}

Earth dykes without protection are sensitive to this phenomenon. The presence of even young trees at the base of the structure on the water-side and particularly on the earth-side increases the risk because the roots penetrate directly in the embankment.

Internal erosion risk is also present on earth dykes with rigid protection where roots are growing in joints and cracks inducing risks of degradation and infiltration increased by the presence of trees implanted on the bank earth-side (in crest, middle or at the base) allowing the roots to cross the entire structure.

The risk on the G3 section is going to be reduced significantly by repair works in progress on the upstream and downstream facing. A root extraction test allowing the characterization of the rooted plane trees on the crest is still expected. Its goal is to ensure that their roots are not able to damage the upstream impermeability.

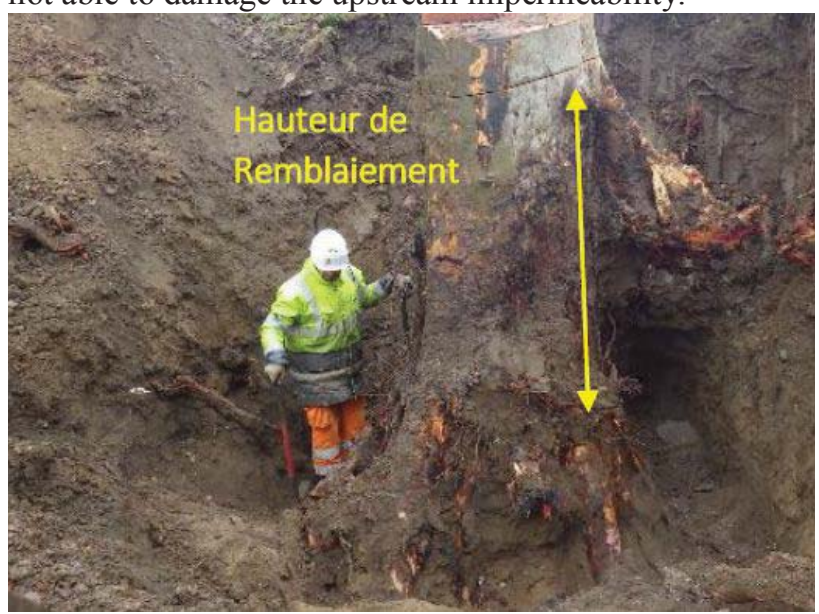

Figure 12. Root extraction test on G3 section- notice an horizontal root through the dyke fill

\subsubsection{Vegetation and external erosion risk}

Earth dykes without protection are more sensitive to this phenomenon, even the presence of young trees at the base of the structure on the water-side generates a degradation risk of the bank with the water flow.

Concerning earth dykes covered by concrete blocks and concrete slab, the initiation of the external erosion mechanism is due to protection default (uprising and/or removal of a concrete block or part of a concrete slab, partially already upraised or degraded by young tree roots).

In the case of gravity walls or retaining walls, no external erosion risk is noticeable.

\subsubsection{Vegetation and instability risk during flooding}

The base of earth dyke without protection of the G0 section may be damaged by flooding on its upstream facing because of the presence of trees on the river-side base of the structure.

The risk on the G3 section will be reduced with repairing works in progress of the upstream facing. However, the instability risk during flooding remains and could be increased with windfall because of the presence of continuous forest on the downstream facing, the presence of plane trees on the crest and the punctually dyke section decreases due to resident gardens.

Plane trees are implanted in the crest of D7 section. The 1875 flood confirms that the platanus implanted on the crest could destroy the parapet inducing a destruction risk in case of swinging of one of the many trees which could break the briquette parapet because of the large size of the trees. 


\subsubsection{Vegetation and Instability risk during receding water}

The Instability risk during receding waters is linked to the enhancement of the infiltration process due to the presence of roots in joints and cracks of the coating (D4) which increases weight of materials and pushes the rigid coating after the flood recession of the Garonne river.

For the briquette walls (D7, D8 and D9) this phenomenon is increased by the presence of large plane trees in the crest which induces an overload and an additional constraint emphasized by wind.

On the D12, D13 and D14 sections, instability risk during receding water is due to clogging of outlets or drains by vegetation and roots thus increasing the under-pressure. This is also valid for gravity walls with outlet drains and/or anti-reverse valves which don't close because of the vegetation growing in it.

\subsubsection{Vegetation and Risk caused by overflow}

On D4 and D14 sections, windfall risk of trees implanted on the crest could reduce the width of the structure and could damage the parapet where there is water contact. This increases overflow risk.

On G3, even if strengthening work of the upstream facing are in progress, the risk of plane tree falling on the crest remains and would generates a decrease of the structure width. The 1875 flood is approximatively at $10 \mathrm{~cm}$ below the crest. Damage risk by swinging on parapet is alto to be considered. This risk will be increased with growing of trees.

Concerning D13 section, only degradation risk of the parapet due to falling trees is to be considered, water contact with the low wall could generate an overflow. However, we notice that actual plane tree dimensions only generate a small risk which will increase over the years when the trees will grow. The lake of joint between walls permits water flow even in a low quantity.

On D7 and G4 sections, the highest water level reaches the parapet and the bigger plane trees can break the low briquette wall. The risk is increased when sanitary and mechanical trees status is bad. It could increase the probability of falling trees.

\subsubsection{Synthesis on vegetation impact on failure risk assessment}

Finally, a vegetation impact level has been assessed for each dyke section according to the vegetation diagnosis and the characteristics of the dyke section.

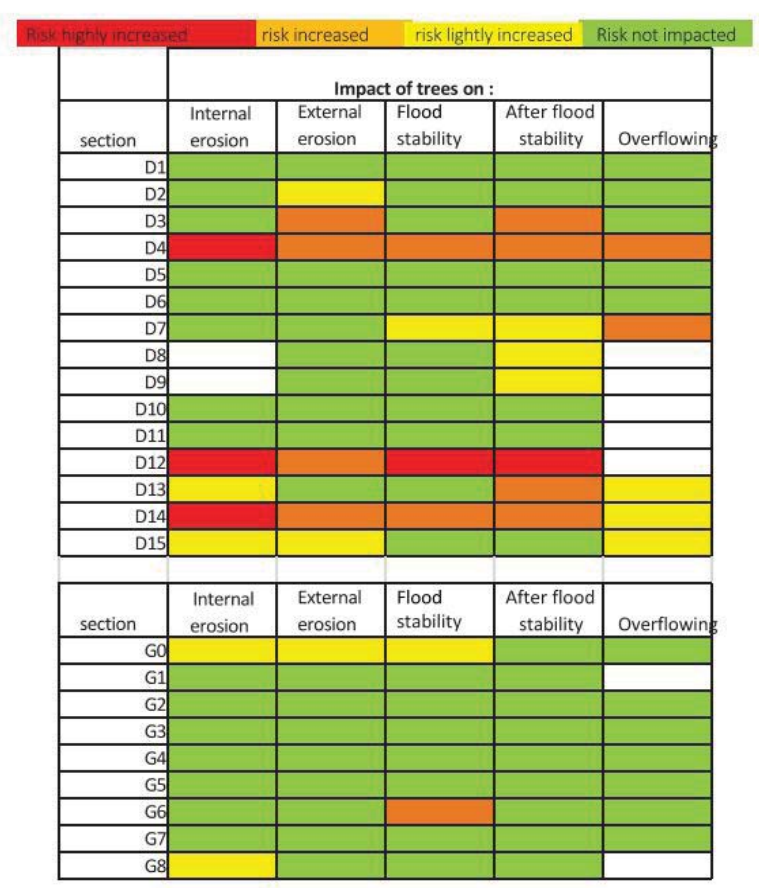

Table 2. Vegetation impact on failure risk assessment

\subsection{Synthesis on failure probability of dykes and buildings}

Once the failure assessment for the 4 main failure modes was done taking into account the impact of vegetation, a probability of failure has been estimated for the 4 different flood levels.

\begin{tabular}{|c|r|r|r|l|}
\hline $\begin{array}{c}\text { Dyke } \\
\text { section }\end{array}$ & $\begin{array}{c}\text { Year } 2000 \\
\text { flood }\end{array}$ & $\begin{array}{c}100 \text { return } \\
\text { period } \\
\text { flood }\end{array}$ & 1875 & $\begin{array}{c}1875+ \\
50 \mathrm{~cm}\end{array}$ \\
\hline D1 bis & $1 . \mathrm{E}-03$ & $1 . \mathrm{E}-03$ & $7 . \mathrm{E}-03$ & $5 . \mathrm{E}-02$ \\
\hline D2 bis & $1 . \mathrm{E}-03$ & $1 . \mathrm{E}-03$ & $7 . \mathrm{E}-03$ & $5 . \mathrm{E}-02$ \\
\hline D3 & $1 . \mathrm{E}-03$ & $1 . \mathrm{E}-03$ & $7 . \mathrm{E}-03$ & $7 . \mathrm{E}-02$ \\
\hline D4 & $6 . \mathrm{E}-02$ & $2 . \mathrm{E}-01$ & $9 . \mathrm{E}-01$ & $9 . \mathrm{E}-01$ \\
\hline D5 & $1 . \mathrm{E}-03$ & $6 . \mathrm{E}-03$ & $1 . \mathrm{E}-02$ & $3 . \mathrm{E}-02$ \\
\hline D6 & $0 . \mathrm{E}+00$ & $0 . \mathrm{E}+00$ & $1 . \mathrm{E}-03$ & $2 . \mathrm{E}-02$ \\
\hline D7 & $0 . \mathrm{E}+00$ & $0 . \mathrm{E}+00$ & $4 . \mathrm{E}-03$ & $5 . \mathrm{E}-02$ \\
\hline D8 & $0 . \mathrm{E}+00$ & $0 . \mathrm{E}+00$ & $1 . \mathrm{E}-03$ & $1 . \mathrm{E}-03$ \\
\hline D9 & $0 . \mathrm{E}+00$ & $0 . \mathrm{E}+00$ & $1 . \mathrm{E}-03$ & $1 . \mathrm{E}-03$ \\
\hline D10 & $0 . \mathrm{E}+00$ & $0 . \mathrm{E}+00$ & $1 . \mathrm{E}-03$ & $1 . \mathrm{E}-03$ \\
\hline D11 & $0 . \mathrm{E}+00$ & $0 . \mathrm{E}+00$ & $1 . \mathrm{E}-03$ & $1 . \mathrm{E}-03$ \\
\hline D12 & $7 . \mathrm{E}-02$ & $2 . \mathrm{E}-01$ & $9 . \mathrm{E}-01$ & $9 . \mathrm{E}-01$ \\
\hline D13 & $0 . \mathrm{E}+00$ & $0 . \mathrm{E}+00$ & $1 . \mathrm{E}-03$ & $4 . \mathrm{E}-03$ \\
\hline D14 & $7 . \mathrm{E}-02$ & $2 . \mathrm{E}-01$ & $9 . \mathrm{E}-01$ & $9 . \mathrm{E}-01$ \\
\hline D15 & $1 . \mathrm{E}-03$ & $1 . \mathrm{E}-02$ & $5 . \mathrm{E}-02$ & $1 . \mathrm{E}-01$ \\
\hline
\end{tabular}

Table 3. Failure probability estimate of right bank dykes for the four flood levels

The design flood, corresponding to conditional probability inferior to about $10 \%$ on existing dykes and to $1 \%$ on new dykes or strengthening projects [4], is the 1875 flood, except for 3 dyke sections. The danger flood, for which the failure probability becomes high, typically 20 to $50 \%$ [4], is higher than the " $1875+50 \mathrm{~cm}$ " flood, 
even though overflowing occurs on some sections for this flood.

\subsection{Flood gates and barriers management}

Toulouse City has developed a comprehensive operational flood management plan [3] including watch on State flood forecasting, and organizational guidelines to face flood in the city according to flood rising speed and 3 typical flood intensity.
In order to close on time 64 gates on sewage networks and 18 gates and barriers on dykes, the City informs the different owners, managers and services of the flood evolution, ask them to close the gates at water levels and verifies it is done.

A detailled analysis of the organiszation and of the timeframe available to close the different gates and barriers has been done and a probability of closing failure has been estimated thanks to fault-tree analysis.

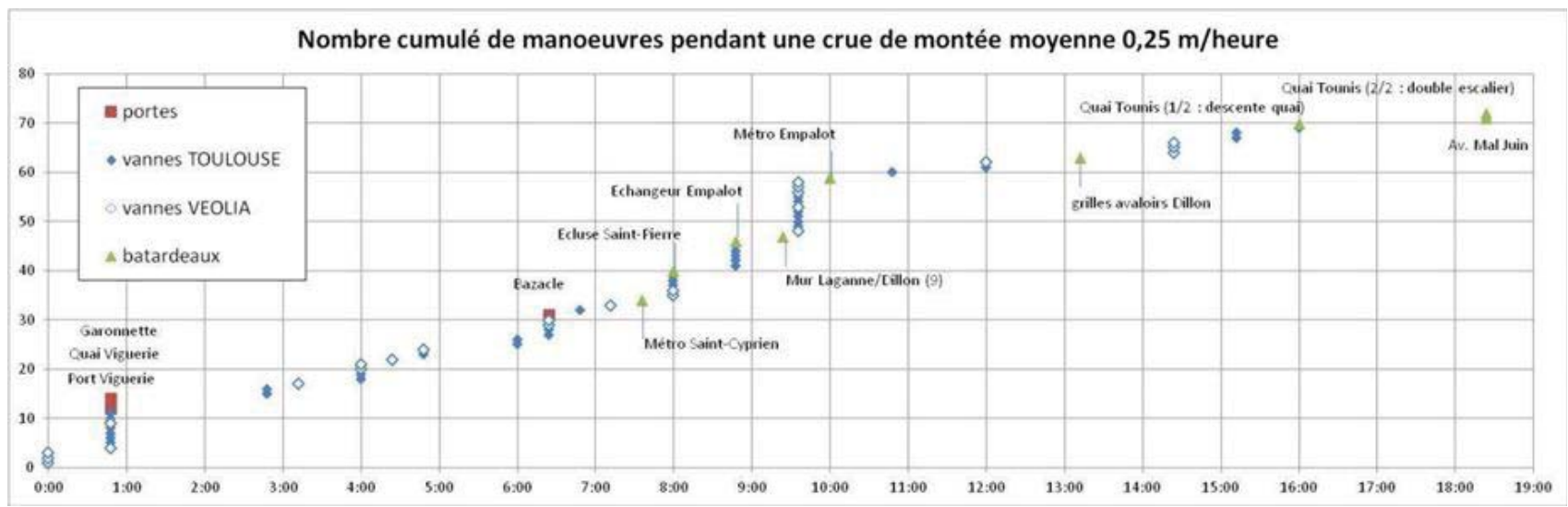

Figure 13. Timeframe analysis of the gate and barriers closing actions

\subsection{Gravity in case of dyke failure}

The gravity in case of dyke failure is assessed thanks to existing and new failure hydraulic models that allow defining the flooded area in case of failure, for different flood levels.

The number of inhabitants in the flooded area is then estimated thanks to the national institute of statistics data.

The City flood management plan plans to alert population and to place to refuge or evacuate if the danger flood level is reached or predicted, according to several alert areas, and enables to reduce gravity.

For D4, D12 and D14 dyke sections that were already known to be at risk, evacuation is planned for lower level than the 1875 design flood, until reinforcement works are achieved.

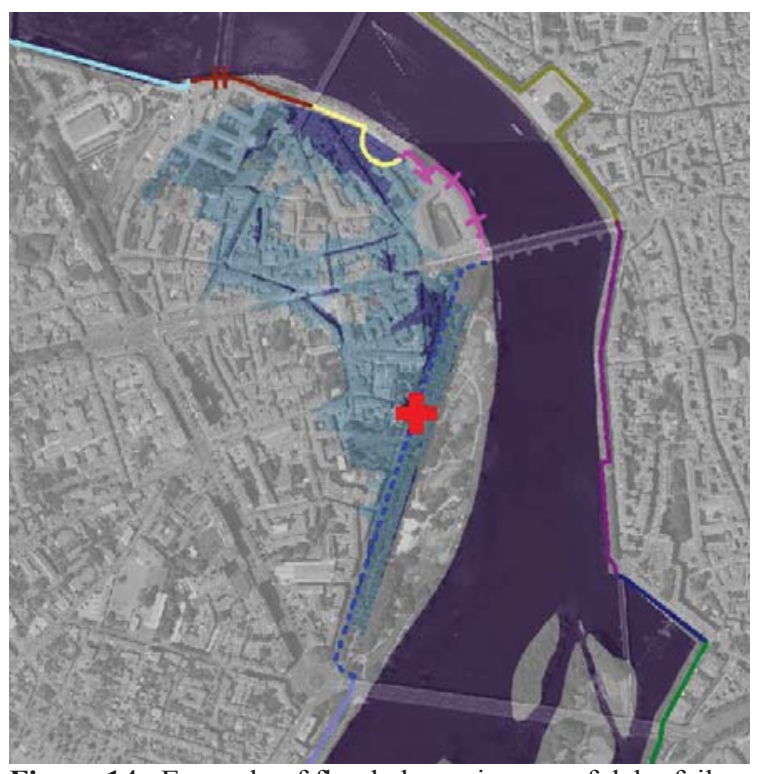

Figure 14. Example of flooded area in case of dyke failure 


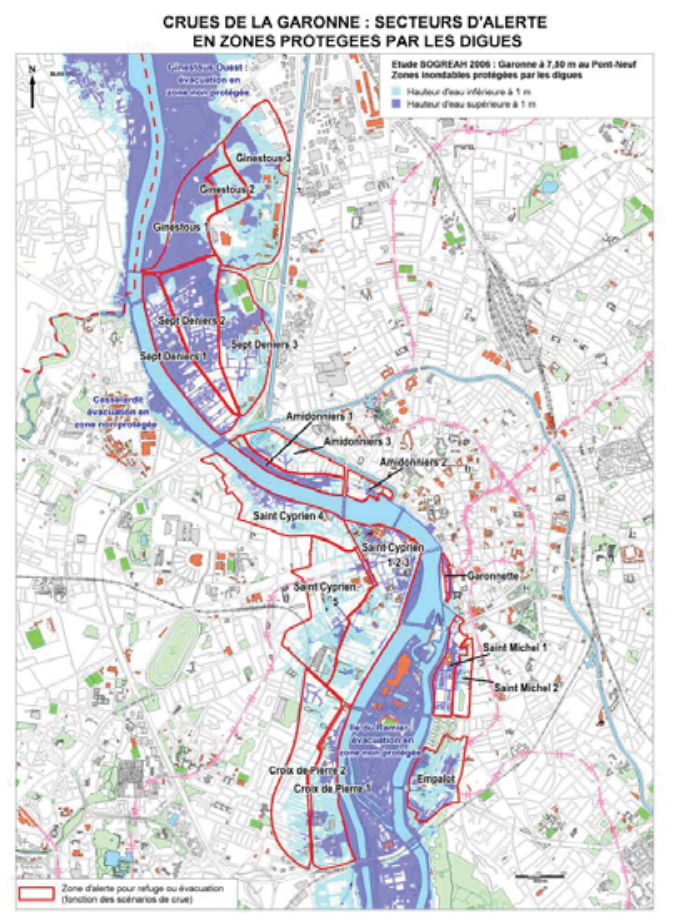

Figure 15. The alert areas (according to Toulouse City)

\subsection{Criticality of dykes}

The criticality is assessed as the sum for each flood level of the product of probability and gravity.

The criticality is found to be acceptable for the different sections, except for D4, D12 and D14 for which it is tolerable.

One of the key results of the study is to demonstrate that even though the 1875 design flood is unlikely, the gravity in case of failure is high and the criticality is acceptable only thanks to prevention evacuation of inhabitants as soon as the design flood is reached or predicted with increasing flow trends.

\begin{tabular}{|l|l|l|l|l|l|l|}
\hline \multicolumn{2}{|c|}{} & \multicolumn{4}{|c|}{ Annual failure probability (P) } \\
\cline { 3 - 6 } & & $\begin{array}{l}1- \\
10^{-1}\end{array}$ & $\begin{array}{l}10^{-1}- \\
10^{-2}\end{array}$ & $\begin{array}{l}10^{-2} \\
-30^{-3}\end{array}$ & $\begin{array}{l}10^{-4} \\
10^{-4}\end{array}$ \\
\hline Probability grade & 5 & 4 & 3 & 2 \\
\hline $\begin{array}{l}\text { Gravity } \\
\text { grade }\end{array}$ & $\begin{array}{l}\text { Inhabitants } \\
\text { in High } \\
\text { hazard area }\end{array}$ & $\begin{array}{l}\text { Inhabitants } \\
\text { in medium } \\
\text { hazard area }\end{array}$ & & & & \\
\hline 4 & $100-1000$ & $\begin{array}{l}1000-10 \\
000\end{array}$ & 9 & 8 & 7 & 6 \\
\hline 3 & $10-100$ & $100-1000$ & 8 & 7 & 6 & 5 \\
\hline 2 & $1-10$ & $10-100$ & 7 & 6 & 5 & 4 \\
\hline 1 & 0 & $1-10$ & 6 & 5 & 4 & 3 \\
\hline 0 & 0 & 0 & 5 & 4 & 3 & 2 \\
\hline
\end{tabular}

Table 4. Extract of the criticality grid used for Toulouse Dykes (green: acceptable; orange: tolerable with ALARP measures; red: unacceptable and needing structural works)

\section{Mitigation measures}

\subsection{Structural reinforcement}

Reinforcement works are planned in the coming years on the dyke sections with the highest probability of failure: D4, D12 and D14, including mainly reinforcement of the upstream facing [11].

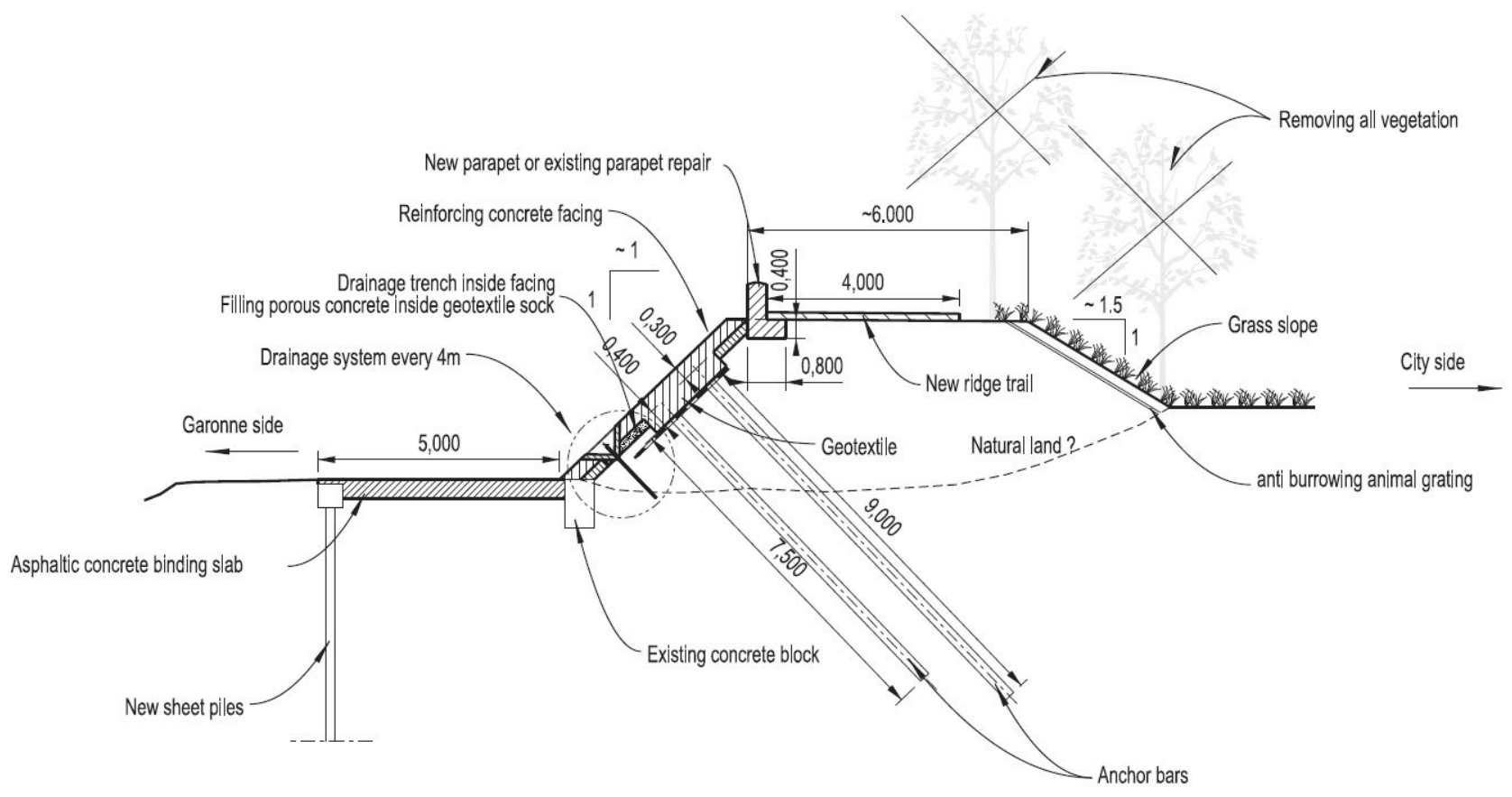

Figure 16. Example of planned reinforcement work on D4 


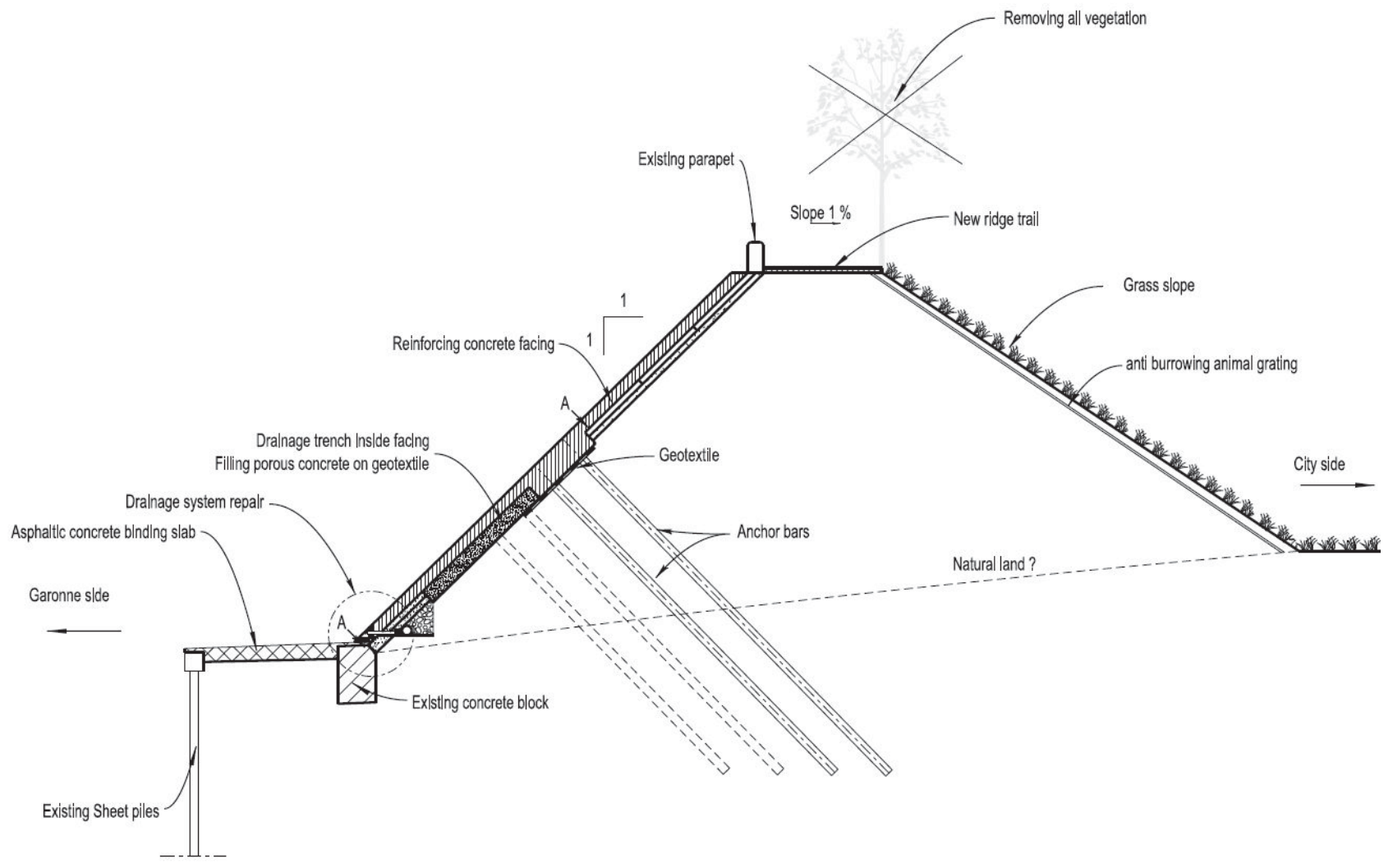

Figure 17. Example of planned reinforcement work on D12 and D14

Some adaptations of openings on buildings have also been made recently, after the study.

\subsection{Vegetation management plan}

The vegetation management plan includes various issues as ecological, landscape and safety presence on dykes of the Garonne river in Toulouse. As a matter of fact, trees implanted in the crest of the dyke constitute shaded pathways which attract many walkers, joggers and cyclists but these pathways are potentially exposed to the risks of falling trees and branches during periods of high wind.

In regard to these risks caused by vegetation implanted on the Toulouse dykes, it appears that D4, D12 and D14 sections are the most critical of all, particularly with internal erosion and instability risks. These sections would have required large excavation work and a purge of the earth-side bank. As a result of strengthening works planned and large cleaning works expected which will be performed in the coming years, works concerning the vegetation control will be reduced. For example, only 43 punctual trees on the 1533 inventoried will have to be quickly treated as well as around 50 among the linear survey.

Phytosanitary and mechanical status monitoring actions of conserved trees on dyke crest should be performed annually, mainly on dyke sections with rigid protections. It has been recommended to contact certified companies for plane treatments to avoid canker strain disease contamination risks.

Warning, alignment trees which present a bad sanitary or mechanical status should be cut down. On dykes with rigid protections on crest, trees will have to be extracted, extraction holes cleaned and dykes reconstructed according to the proper rules.

\subsection{Dyke and flood management}

The study has identified closing dyke sections that were not previously identified as dykes. These new sections will have to be maintained as flood dykes.

The organization is essential both for flood gates and barriers closing and for evacuation in case of extreme flood. Some mitigation measures are made on the City flood management plan, including the need of regular training emergency exercises and the need to ensure external owners and managers of flood barriers and barriers are sufficiently organized to fulfil their duty within the general organization framework and timeframe.

\subsection{Expected criticality reduction}

Combining reinforcement works and non-structural measures will enable to reduce criticality of dykes (cf table 5). 


\begin{tabular}{|l|r|r|}
\hline Dyke section & $\begin{array}{c}\text { Present criticality } \\
\text { grade }\end{array}$ & $\begin{array}{c}\text { After works and } \\
\text { measures criticality }\end{array}$ \\
\hline D1 bis & 1 & 1 \\
\hline D2 bis & 1 & 1 \\
\hline D3 & 1 & 1 \\
\hline D4 & $\mathbf{3}$ & $\mathbf{5}$ \\
\hline D5 & 4 & 6 \\
\hline D6 & 5 & 5 \\
\hline D7 & $\mathbf{4}$ & $\mathbf{5}$ \\
\hline D8 & 0 & 0 \\
\hline D9 & 0 & 0 \\
\hline D10 & $\mathbf{1}$ & $\mathbf{4}$ \\
\hline D11 & $\mathbf{1}$ & $\mathbf{5}$ \\
\hline D12 & $\mathbf{6}$ & $\mathbf{6}$ \\
\hline D13 & $\mathbf{3}$ & $\mathbf{5}$ \\
\hline D14 & $\mathbf{6}$ & $\mathbf{5}$ \\
\hline D15 & 3 & 3 \\
\hline
\end{tabular}

10. Vennetier, Mériaux, Zanetti (2015), Gestion de la végétation des ouvrages hydrauliques en remblai. Cardère éditeur.

11. Quatremarre (ISL) et al (2013), Stenghtening of flood protection dikes in Toulouse: rising safety level of dikes with an unusual design, and which never experienced major flood, up to modern safety standards, 2ième colloque national Digue2013. in bold

\section{Acknowledgments}

This work was conducted in collaboration with the different dyke owners: DDT31, City of Toulouse, Toulouse Hospital (CHU), DIRSO, EDF, Martinet hydropowerplant, VNF.

\section{References}

0. French State (2000), Circulaire du 16/04/10 relative aux études de dangers des digues de protection contre les inondations fluviales

1. ISL Ingénierie (2016), Digues de protection contre les crues de la ville de Toulouse, Etude de dangers des digues.

2. Arbeausolutions (2015), Diagnostic de la végétation sur les digues de la Garonne à Toulouse et préconisations de gestion.

3. Mairie de Toulouse (2015), Plan communal en cas d'inondation par la Garonne.

4. Mallet, Degoutte, Royet (2013), Protection, safety and danger levels for levees, definition, consequences and responsabilities, 2ième colloque national Digue2013.

5. Lino (ISL), Mériaux, Royet (2000). Méthodologie de diagnostic des digues appliquées aux levées de la Loire Moyenne, Cemagref

6. Mériaux, Royet, Folton (2001). Monitoring, maintenance and diagnosis of dikes: a practical guide for owners and managers. Cemagref.

7. Deroo (ISL), Fry (2013). ERINOH Guidelines (volume $3)$ : control of internal erosion, 2ième colloque national Digue2013.

8. IREX, Deroo (ISL), Fry (EDF-CIH) (to be published), ERINOH internal erosion engineering guide

9. Lane (1935). Security from underseepage, masonry dams on earth foundations, 